ISSN 1678-3921

Journal homepage: www.embrapa.br/pab

For manuscript submission and journal contents, access: www.scielo.br/pab

\section{Pruning management of mini-stumps for mass propagation of blueberry}

\begin{abstract}
The objective of this work was to evaluate the influence of the pruning management of mini-stumps of the Climax blueberry cultivar, when weekly fertigated, on the productivity of the clonal mini-garden and on the rooting and root vigor of the mini-cuttings. The high survival of the ministumps $(100 \%)$ and production of the mini-cuttings (182.9 mini-cuttings per square meter per month) evidence the high adaptability of the material to successive samplings and to the nutritional conditions provided to the clonal mini-garden, resulting in a high multiplication rate. The rooting percentages obtained at the different samplings remain stable, with a high average of rooted mini-cuttings, reaching $81.7 \%$.
\end{abstract}

Index terms: Vaccinium, clonal mini-garden, clonal seedling, mini-cuttings, root vigor, vegetative propagation.

\section{Manejo de poda de minicepas para propagação massal de mirtilo}

Carlos André Stuepp ${ }^{(1 \otimes)}(\mathbb{D}$, Bruna Aparecida do Amaral ${ }^{(1)}$ (D), Ricardo Antonio Ayub (1) (1) and Rosimeri de Oliveira Fragoso(2) (DD

(1) Universidade Estadual de Ponta Grossa, Departamento de Fitotecnia e Fitossanidade, Campus de Uvaranas, Avenida General Carlos Cavalcanti, no 4.748, Uvaranas, CEP 84030-900 Ponta Grossa, PR, Brazil. E-mail: castuepp@uepg.br, bruninhapr97@hotmail.com, rayub@uepg.br

(2) Universidade Estadual de Ponta Grossa, Departamento de Biologia Geral Campus de Uvaranas, Avenida General Carlos Cavalcanti, № 4.748, Uvaranas, CEP 84030-900 Ponta Grossa, PR, Brazil. E-mail: meri_ol@yahoo.com.br

$\bowtie$ Corresponding author

Received

June 01, 2020

Accepted

June 23, 2021

How to cite

STUEPP, C.A.; AMARAL, B.A. do;

AYUB, R.A.; FRAGOSO, R. de O.

Pruning management of mini-stumps for mass propagation of blueberry. Pesquisa Agropecuária Brasileira, v.56, e02486, 2021 DOI: https://doi.org/10.1590/S1678-3921. pab2021.v56.02486.
Resumo - O objetivo deste trabalho foi avaliar a influência do manejo de poda de minicepas da cultivar Climax de mirtilo, quando fertirrigadas semanalmente, sobre a produtividade do minijardim clonal e sobre o enraizamento e o vigor radicial das miniestacas. As elevadas sobrevivência das minicepas $(100 \%)$ e produção de miniestacas (182,9 miniestacas por metro quadrado por mês) evidenciam a boa adaptação do material às coletas sucessivas e às condições nutricionais fornecidas ao minijardim clonal, o que resultou em alta taxa de multiplicação. Os percentuais de enraizamento obtidos nas diferentes coletas se mantêm estáveis, com média elevada de miniestacas enraizadas, que alcança $81,7 \%$.

Termos para indexação: Vaccinium, minijardim clonal, mudas clonais, miniestacas, vigor radicial, propagação vegetativa.

The absence of efficient technologies for the production of blueberry (Vaccinium L.), of the family Ericaceae, has been a limiting factor for the expansion of cultivated areas in Brazil (Schuch \& Tomaz, 2019). Commercially produced through the cuttings technique, matrices undergo a rapid maturation process, resulting in modest rooting percentages even when plant regulators are used (Marangon \& Biasi, 2013). New techniques and methods have been applied to improve the juvenile vigor of propagules, which is directly related to endogenous concentrations of auxins and cofactors, such as carbohydrates and phenolic compounds, essential for the rooting process (Kazan, 2013).

Mini-cutting is an evolution of the traditional cutting technique, which increases the control of the morphophysiological characteristics 
of propagule donor matrices (Xavier et al., 2013). This control occurs through the management of the clonal mini-garden and, when done properly, can amplify morphophysiological characteristics of interest for rhizogenesis, such as youthful vigor, potentiating the rooting success of mini-cuttings (Stuepp et al., 2016). The mini-cutting technique was initially developed for forest species, but has been considered for the vegetative propagation of fruit trees that do not need to reach a high degree of maturity (Stuepp et al., 2018), such as blueberry.

Therefore, it is possible to formulate a hypothesis that the pruning management of blueberry ministumps, under fertigation, favors the maintenance of the vegetative vigor of the clonal mini-garden and the emission ability of the adventitious roots of vegetative propagules.

The objective of this work was to evaluate the influence of the pruning management of mini-stumps of the Climax blueberry cultivar, when weekly fertigated, on the productivity of the clonal minigarden and on the rooting and root vigor of the minicuttings.

The experiment was conducted between October 2018 and April 2019, at the forest nursery of Universidade Estadual de Ponta Grossa, located in the municipality of Ponta Grossa, in the state of Paraná, Brazil. According to Köppen-Geiger's classification, the climate of the region is temperate, of the Cfb type, always humid, with well-distributed rains throughout the year, with the temperature of the coldest month between -3 and $18^{\circ} \mathrm{C}$ and of the warmest month below $22^{\circ} \mathrm{C}$.

The clonal mini-garden of the Climax blueberry cultivar, installed in June 2018, was formed by plants produced from cuttings. The mini-stumps were grown under full sunlight, in $1.0 \mathrm{~L}$ pots filled with $50 \%$ subsoil, 20\% Carolina Soil substrate (Plantei Garden Center, Salto Grande, SP, Brazil), 20\% decomposed yerba mate, and $10 \%$ charred yerba mate (biochar). A total of 69 mini-stumps were planted per square meter, receiving micro-sprinkler irrigation twice a day for $10 \mathrm{~min}$ at flow rate of $144 \mathrm{~L} \mathrm{~h}^{-1}$. The clonal mini-garden was weekly fertigated with $20 \mathrm{~mL}$ of the following nutrient solution per mini-stump: $3.0 \mathrm{~g} \mathrm{~L}^{-1}$ monoammonium phosphate, $4.0 \mathrm{~g} \mathrm{~L}^{-1}$ Yoorin fertilizer (Yoorin Fertilizantes, Poços de Caldas, MG, Brazil), $4.0 \mathrm{~g} \mathrm{~L}^{-1}$ potassium chloride, $3.0 \mathrm{~g} \mathrm{~L}^{-1}$ ammonium sulfate, and $1.0 \mathrm{~g} \mathrm{~L}^{-1}$ Dripsol Micro Rexene Equilíbrio micronutrient mixture (SQM Vitas Brasil, Candeias, BA, Brazil).

The clonal mini-garden was implanted in a completely randomized design, with five replicates of 20 mini-stumps per experimental unit, totaling 100 mini-stumps. During three successive samplings, the survival rate of mini-stumps, the production of minicuttings per mini-stump, and the production of minicuttings per square meter per month were evaluated.

Shoots longer than $8.0 \pm 1.0 \mathrm{~cm}$ were collected to produce the mini-cuttings. From these, mini-cuttings with $6.0 \pm 1.0 \mathrm{~cm}$ length and $0.2 \pm 0.1 \mathrm{~cm}$ average diameter were prepared, maintaining two pairs of leaves reduced to $50 \%$ of their original surface area. The mini-cuttings were planted in $55 \mathrm{~cm}^{3}$ polypropylene tubes filled with Carolina Soil substrate (Plantei Garden Center, Salto Grande, SP, Brazil) up to a depth of $2.0 \mathrm{~cm}$. Subsequently, the mini-cuttings were placed in a rooting environment, and irrigated by nebulization every $5 \mathrm{~min}$, for $20 \mathrm{~s}$, at a flow rate of 28 $\mathrm{L} \mathrm{h}^{-1}$, from 7:00 a.m. to 7:00 p.m., without temperature control.

Sixty days after the mini-cuttings were planted, the following variables were assessed: rooting percentage, number of roots per mini-cutting, length of the three largest roots per mini-cutting $(\mathrm{cm})$, percentage of minicuttings with calluses, percentage of live mini-cuttings without roots and calluses, percentage of dead minicuttings, shoot emission percentage, and percentage of mini-cuttings that kept their original leaves.

The multiplication rate was calculated from the productivity of mini-stumps and rooting of minicuttings, according to the formula: $\mathrm{MR}=\mathrm{PSM} \mathrm{x}$ Rooting (\%), where MR is the multiplication rate and PSM is the production of mini-cuttings per square meter per month.

The rooting experiment was installed in a completely randomized design, with three treatments (sampling times) and four replicates of $20 \mathrm{mini}-$ cuttings per experimental unit. The sampling dates of the mini-cuttings were: 12/8/2018 (sampling 1), 1/13/2019 (sampling 2), and 2/11/2019 (sampling $3)$. The homogeneity of variances was verified by Bartlett's test at $5 \%$ probability and, subsequently, the data were subjected to the analysis of variance. When statistically significant, the means of the variables were subjected to Tukey's test at 5\% probability. 
The high survival percentage of the mini-stumps of the Climax blueberry cultivar, which remained at 100\% after three successive samplings, supports the high adaptability of the material to the selective sampling protocol, as well as to the nutritional management of the clonal mini-garden, since the mini-stumps maintained their vigor throughout the experimental period. Moreover, there was no significant difference in the production of mini-cuttings per square meter per month between samplings, with a peak of 182.9 minicuttings per square meter per month (Figure $1 \mathrm{~A}$ ) and an average productivity of 1.6 mini-cutting per ministump in the three samplings.
The evaluated model of propagule production is highly dependent on biomass and root system morphology, which determine the plant's ability to recover after stress caused by successive pruning (Xavier et al., 2013). Therefore, the nutritional replacement via weekly fertigation proved to be efficient to support the good vegetative performance of the mini-stumps, which emitted young shoots and leaves, favoring nutrient uptake from the substrate and stump recovery, with no signs of phytotoxicity.

Regarding the rooting percentages of the minicuttings, the mean values remained stable, with an average of $81.7 \%$ rooted mini-cuttings in the three
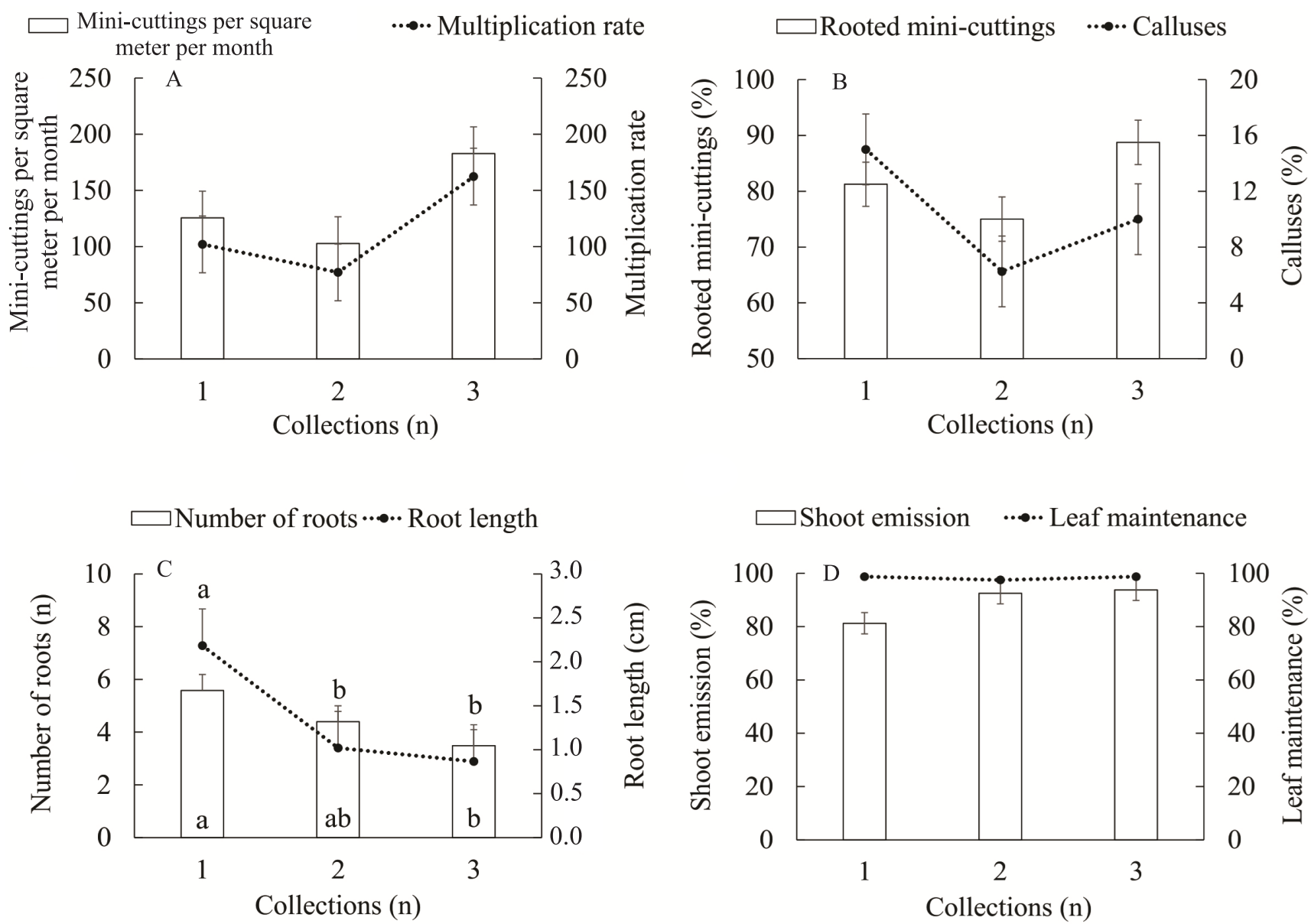

Figure 1. Mean values for production of mini-cuttings per square meter per month and multiplication rate (A), rooted minicuttings and mini-cuttings with calluses (B), number of roots and length of the three largest roots per mini-cutting (C), and shoot emission and leaf maintenance of mini-cuttings (D) of the Climax blueberry (Vaccinium sp.) cultivar in three sampling dates (12/8/2018, 1/13/2019, and 2/11/2019) in the municipality of Ponta Grossa, in the state of Paraná, Brazil. Bars indicate the mean standard error according to Tukey's test, at 5\% probability. Mean values followed by equal letters do not differ between variables. 
samplings (Figure $1 \mathrm{~B}$ ). The highest value of $88.8 \%$ for this variable was found in the third sampling and did not differ statistically from the others. These high percentages of rooting, greater than those obtained in another study with blueberry mini-cuttings using plant regulators (Colombo et al., 2018), confirm the hypothesis that the maintenance of mini-stumps under successive samplings, associated with an adequate nutritional management, favors the ability of the Climax blueberry cultivar to emit adventitious roots. It is known that the adequate supply of macro- and micronutrients, mainly of nitrogen (Zerche \& Druege, 2009), is strongly associated with the rhizogenesis process and, therefore, with the success of minicuttings (Xavier et al., 2013).

All rooted mini-cuttings presented calluses, which indicates a dependence on previous callus formation for a further dedifferentiation of adventitious roots. However, the percentage of mini-cuttings only with calluses was low, not exceeding $15 \%$ in the first sampling (Figure 1 B). During rhizogenesis, adventitious roots can arise from either direct or indirect routes, depending on auxin concentrations and metabolic stability (Costa et al., 2013). The direct route usually occurs from cambial zones, and the indirect one, when masses of undifferentiated cells (calluses) form initially, later differentiating into adventitious roots (Druege et al., 2019). However, for the Climax blueberry cultivar, further studies are needed to understand these changes and their consequences on the vegetative propagation of the species. The percentage of live mini-cuttings was also low, with an average of $7.9 \%$ in the three samplings, and there were no dead mini-cuttings.

Although no significant difference was observed between the three samplings for the rooting variable, there was a significant reduction in the vigor of the mini-cuttings in the second sampling, evidenced by the reduction in the number and length of the three largest roots (Figure $1 \mathrm{C}$ ). This reduction in root vigor may be indirectly related to the pruning management of the mini-stumps, due to the high percentage of sprouts induced by the successive samplings. In fact, there was an increase in mini-cutting shoots between the first and third samplings (Figure 1 D), which was attributed to the interruption of apical dominance in the propagules caused by the removal of the stem apex when the mini-cuttings were prepared. In addition, vegetative vigor, a characteristic of the Climax cultivar (Radunz et al., 2018) that is an advantage for assessing the productivity of mini-stumps, may limit the rooting of mini-cuttings. This occurs because the high emission of sprouts before that of adventitious roots in the mini-cuttings depletes carbohydrate reserves, hindering rooting (Ruedell et al., 2015).

Following the trend observed for rooting, the percentage of mini-cuttings that maintained their original leaves after 60 days was higher than $97.5 \%$ in the three samplings (Figure 1 D). However, the relationship between adventitious rooting and carbohydrate metabolism is still poorly understood, although there are studies that show the importance of the latter as an energy source for the synthesis of essential substances, such as auxins, which are directly related to rhizogenesis (Xavier et al., 2013; Fragoso et al., 2015).

Efficient methods that can provide large amounts of propagules with high rooting percentages should be sought for the commercial propagation of the evaluated plant species. For the Climax blueberry cultivar, this was achieved in the present study, as evidenced by the high survival of mini-stumps, propagule productivity, and rooting of mini-cuttings, resulting in a high multiplication rate. Therefore, there is solid evidence that it is possible to obtain satisfactory rooting percentages by controlling the main factors that affect vegetative propagation in clonal mini-gardens, in this case, mini-stump pruning and nutritional management.

\section{References}

COLOMBO, R.C.; CARVALHO, D.U. de; CRUZ, M.A. da; ROBERTO, S.R. Blueberry propagation by minicuttings in response to substrates and indolebutyric acid application methods. Journal of Agricultural Science, v.10, p.450-458, 2018. DOI: https://doi.org/10.5539/jas.v10n9p450.

COSTA, C.T. da; ALMEIDA, M.R. de; RUEDELL, C.M.; SCHWAMBACH, J.; MARASCHIN, F.S.; FETT-NETO, A.G. When stress and development go hand in hand: main hormonal controls of adventitious rooting in cuttings. Frontiers in Plant Science, v.4, art.133, 2013. DOI: https://doi.org/10.3389/ fpls.2013.00133.

DRUEGE, U.; HILO, A.; PÉREZ-PÉREZ, J.M.; KLOPOTEK, Y.; ACOSTA, M.; SHAHINNIA, F.; ZERCHE, S.; FRANKEN, P.; HAJIREZAEI, M.R. Molecular and physiological control of adventitious rooting in cuttings: phytohormone action meets resource allocation. Annals of Botany, v.123, p.929-949, 2019. DOI: https://doi.org/10.1093/aob/mcy234. 
FRAGOSO, R. de O.; WITT, N.G. de P.M.; OBRZUT, V.V.; VALÉRIO, S.; ZUFFELLATO-RIBAS, K.C.; STUEPP, C.A. Maintenance of leaves and indolebutyric acid in rooting of juvenile Japanese flowering cherry cuttings. Revista Brasileira de Ciências Agrárias, v.10, p.97-101, 2015. DOI: https://doi.org/10.5039/agraria.v10ila5111.

KAZAN, K. Auxin and the integration of environmental signals into plant root development. Annals of Botany, v.112, p.16551665, 2013. DOI: https://doi.org/10.1093/aob/mct229.

MARANGON, M.A.; BIASI, L.A. Estaquia de mirtilo nas estações do ano com ácido indolbutírico e aquecimento do substrato. Pesquisa Agropecuária Brasileira, v.48, p.25-32, 2013. DOI: https://doi.org/10.1590/S0100-204X2013000100004.

RADUNZ, A.L.; SCHEUNEMANN, L.C.; KRÖNING, D.P.; HERTER, F.G.; REICHERT JUNIOR, F.W.; RADUNZ, M.; SILVA, V.N. Characterization of blueberry cultivar 'Climax'. Acta Scientiarum. Biological Sciences, v.40, e40472, 2018. DOI: https://doi.org/10.4025/actascibiolsci.v40i1.40472.

RUEDELL, C.M.; ALMEIDA, M.R. de; FETT-NETO, A.G. Concerted transcription of auxin and carbohydrate homeostasisrelated genes underlies improved adventitious rooting of microcuttings derived from far-red treated Eucalyptus globulus
Labill mother plants. Plant Physiology and Biochemistry, v.97, p.11-19, 2015. DOI: https://doi.org/10.1016/j.plaphy.2015.09.005.

SCHUCH, M.W.; TOMAZ, Z.F.P. Advances in the spread of vegetative blueberry. Revista Brasileira de Fruticultura, v.41, e-041, 2019. DOI: https://doi.org/10.1590/0100-29452019041.

STUEPP, C.A.; FRAGOSO, R. de O.; MAGGIONI, R. de A.; LATOH, L.P.; WENDLING, I.; ZUFFELLATO-RIBAS, K.C. Ex vitro system for Acer palmatum plants propagation by minicuttings technique. Cerne, v.22, p.355-364, 2016. DOI: https://doi. org/10.1590/01047760201622032147.

STUEPP, C.A.; WENDLING, I.; XAVIER, A.; ZUFFELLATORIBAS, K.C. Vegetative propagation and application of clonal forestry in Brazilian native tree species. Pesquisa Agropecuária Brasileira, v.53, p.985-1002, 2018. DOI: https://doi.org/10.1590/ S0100-204X2018000900002.

XAVIER, A.; WENDLING, I.; SILVA, R.L. da. Silvicultura clonal: princípios e técnicas. 2.ed. rev. e ampl. Viçosa: Ed. UFV, 2013. 278p.

ZERCHE, S.; DRUEGE, U. Nitrogen content determines adventitious rooting in Euphorbia pulcherrima under adequate light independently of pre-rooting carbohydrate depletion of cuttings. Scientia Horticulturae, v.121, p.340-347, 2009. DOI: https://doi.org/10.1016/j.scienta.2009.02.012. 